\title{
OPTIMALISASI PEMANFAATAN SARANA DAN PRASARANA BELAJAR DI SMA SWASTA PELITA RAYA KOTA JAMBI
}

\author{
Mohamad Muspawi, Peavey Resa Claudia \\ Prodi Administrasi Pendidikan, Fak. Keguruan dan Ilmu Pendidikan, Universitas Jambi \\ E-mail: muspawi01@gmail.com; peavey18@gmail.com
}

\begin{abstract}
ABSTRAK
Tujuan penelitian ini untuk mengetahui sarana dan prasarana belajar yang dimiliki serta pemanfaatan sarana dan prasarana oleh guru dan kualitas sarana dan prasarana di SMA Swasta Pelita Raya Kota Jambi. Pendekatan yang digunakan dalam penelitian ini adalah pendekatan deskriptif kualitatif dengan jenis penelitian studi kasus (case study) yaitu suatu metode yang bertujuan untuk mengungkapkan kejadian atau fakta, keadaan, fenomena, variabel dan keadaan yang terjadi saat penelitian berlangsung dengan menyuguhkan apa yang sebenarnya terjadi. Teknik pengumpulan data menggunakan teknik wawancara, observasi, dokumentasi. Objek penelitian ini meliputi berbagai pihak, yaitu kepala sekolah, waka bidang sarana dan prasarana, dan guru. Hasil penelitian menunjukkan sarana dan prasarana belajar di SMA Swasta Pelita Raya sudah memenuhi standar, guru telah memanfaatkan sarana dan prasarana belajar untuk menunjang kegiatan belajar mengajar menjadi efektif serta memudahkan guru memberikan materi pelajaran kepada siswa, akan tetapi ditemukan kendala dalam hal pembaharuan, ada beberapa sarana dan prasarana sudah tidak layak pakai tetapi belum diperbaharui oleh pihak sekolah, hal ini menyebabkan terkendalanya guru dalam proses belajar mengajar. Berdasarkan penelitian ini disarankan agar memberikan perhatian maksimal terhadap keadaan ruang kelas dan cepat dalam memperbaiki sarana dan prasarana belajar di kelas yang sudah tidak layak agar proses belajar mengajar dapat berjalan dengan efektif.
\end{abstract}

Kata kunci: Pemanfaatan, Sarana dan Prasarana.

\section{PENDAHULUAN}

Pendidikan merupakan hal yang sangat penting bagi manusia, karena dengan pendidikan akan menghantarkan mereka menjadi manusia seutuhnya (Muspawi, 2017:174) dan tentunya juga dengan pendidikan akan menghantarkan manusia pada kehidupan yang lebih maju. Indonesia merupakan negara yang tergolong sebagai negara berkembang di dunia saat ini, potensi negara Indonesia sebenarnya tergolong sangat baik, tetapi sumber daya manusia Indonesia yang kurang dapat memanfaatkan keaadaan potensi ini. Untuk mencapai kemakmuran negara Indonesia diperlukan adanya pendidikan yang baik dan berkompeten sesuai kurikulum yang ada. Lembaga pendidikan merupakan salah satu tempat bagi peserta didik yang disiapkan untuk menjadi manusia berkualitas. 
Sekolah diharapkan dapat membantu menyukseskan program pemerintah Republik Indonesia dalam bidang pendidikan. Tertera dalam UU Nomor 20 Tahun 2003 tentang Sistem Pendidikan Nasional yang menjelaskan tentang fungsi pendidikan nasional yaitu mengembangkan kemampuan dan membentuk watak serta peradaban bangsa yang bermartabat dalam rangka mencerdaskan kehidupan bangsa, bertujuan untuk berkembangnya potensi siswa agar menjadi manusia yang beriman dan bertakwa kepada Tuhan Yang Maha Esa, berakhlak mulia, sehat, berilmu, cakap, kreatif, mandiri, dan menjadi warga negara yang demokratis serta bertanggung jawab.

Berbagai pihak terkait baik pemerintah, guru, maupun siswa harus berupaya meningkatkan mutu Pendidikan. Salah satu faktor yang mampu menunjang efektivitas guru adalah sarana dan prasarana yang berada di sekolah. Baik itu yang bersifat internal maupun eksternal. Dalam pelaksanaannya, kegiatan yang dilakukan oleh suatu lembaga pendidikan harus memperhatikan dua komponen utama yaitu peserta didik dan guru. Mereka melakukan interaksi yang disebut kegiatan belajar mengajar, proses belajar mengajar bisa terlaksana jika komponen penunjang pembelajaran dapat terpenuhi antara lain kinerja guru dalam menyajikan pembelajaran.

Kelengkapan media belajar yang ada di sekolah seperti buku-buku yang diperlukan dan sarana belajar belajar lainnya dapat menunjang keberhasilan guru dalam kegiatan pembelajaran. Secara rasional kegiatan pembelajaran terlaksana secara optimal, apabila sumber belajarnya lengkap dan berfungsi menunjang kegiatan tersebut. Kelengkapan sumber belajar belum menjamin terlaksananya kegiatan pembelajaran yang optimal. Kepala sekolah perlu mengelola sumber belajar tersebut dengan kepemimpinan yang efektif, sehingga sumber belajar yang ada dapat berfungsi menunjang guru dalam melaksanakan tugasnya. Oleh karena itu perlu adanya sarana dan prasarana yang mendukung profesionalitas guru dalam pelaksanaan pembelajaran. Sarana pendidikan adalah semua perangkat peralatan, bahan, dan perabot yang secara langsung digunakan dalam proses pendidikan di sekolah (Depdiknas, 2008), sementara itu prasarana secara etimologi (arti kata) berarti alat tidak langsung untuk mencapai tujuan (Kasan, 2009). sedangkan prasarana pendidikan adalah fasilitas yang secara tidak langsung menunjang jalannya proses pendidikan atau pengajaran, seperti halaman, kebun, taman sekolah, jalan menuju sekolah (Mulyasa, 2003).

Barnawi dan Arifin (2014:49-50) menyatakan bahwa sarana pendidikan dapat diklasifikasikan menjadi tiga macam, yaitu: a. Habis tidaknya, ada dua macam yaitu: 1) Sarana pendidikan yang habis dipakai. 2) Sarana pendidikan yang tahan lama. b. Bergerak tidaknya, ada dua macam yaitu: 1) Sarana pendidikan yang bergerak merupakan sarana pendidikan yang dapat digerakkan atau dipindah-tempatkan.2) Sarana pendidikan yang tidak bergerak. c. Hubungan dengan proses pembelajaran, ada 3 macam yaitu: 1) alat pelajaran, 2) alat peraga, 3) media pembelajaran. Sedangkan Bafadal (2008:3) mengklasifikasikan prasarana pendidikan menjadi dua macam, yaitu: 1. Prasarana pendidikan yang secara langsung digunakan untuk proses belajar mengajar. 2. Prasarana sekolah yang keberadaannya tidak digunakan untuk proses belajar mengajar, tetapi secara langsung sangat menunjang terjadinya proses belajar mengajar. Misalnya, ruang kantor, kantin sekolah, WC dan lain sebagainya.

Djamarah (2000) mengatakan salah satu penunjang keberhasilan pendidikan adalah sarana prasarana pendidikan, yang mengacu pada standar sarana dan prasarana yang dikembangkan oleh BSNP dan ditetapkan dengan Peraturan Menteri, hal itu seringkali menjadi kendala dalam proses penyelenggaraan pendidikan di sekolah. Kendala-kendala yang dihadapi antara lain adalah adanya penyediaan sarana yang belum memadai atau lengkap. Sarana dan prasarana yang tidak memadai dan tidak lengkap dapat menghambat dalam proses belajar mengajar maka dari itu perlu sekali 
adanya penanganan dalam kendala kendala yang timbul agar terwujudnya keberhasilan pendidikan dalam proses belajar mengajar.

Margono (2005:54) menyebutkan pula "permasalahan sarana dan prasarana sangat penting untuk ditangani lebih serius, karena sangat berpengaruh dalam kelancaran proses belajar mengajar, karena disamping menjadi lebih nyaman, juga sekaligus menjadi media pembelajaran dengan peralatan yang harus disesuaikan termasuk penyediaan fasilitas yang mutlak harus dipenuhi, yang tentunya kesemuanya itu harus sesuai dengan kebutuhan dan perkembangan ilmu dan pengetahuan. Seringkali dalam pemenuhan sarana dan prasana ditentukan oleh pihak sekolah bersama komite sekolah berdasar pada keinginan dan kebutuhan sekolah masing-masing semata."

Sekolah-sekolah yang telah memenuhi sarana dan prasarananya akan meningkatkannya agar lebih baik lagi, hal ini adalah wajar sebagai upaya untuk meningkatkan kualitas proses belajar mengajar yang pada tujuannnya untuk meningkatkan kualitas pendidikan itu sendiri. Adapun permasalahan yang sering timbul adalah tidak terkendalinya rencana yang diprogramkan oleh pihak sekolah dengan harapan untuk memenuhi keinginan secara maksimal yang seringkali kurang efektif karena tidak langsung dapat digunakan untuk memenuhi kebutuhan siswa di sekolah yang bersangkutan. Bagaimanapun juga peningkatan kualitas sekolah memang bukan hal yang mudah, terutama jika alokasi anggaran pendidikan di suatu daerah belum memungkinkan untuk mencapai angka ideal.

Termuat dalam Peraturan Pemerintah Republik Indonesia No. 19 Tahun 2005 pada Bab VII Pasal 42 tentang standar sarana prasarana menyebutkan bahwa (1) Setiap satuan pendidikan wajib memiliki sarana yang meliputi perabot, peralatan pendidikan, media pendidikan, buku dan sumber belajar lainnya, bahan habis pakai, serta perlengkapan lain yang diperlukan untuk menunjang proses pembelajaran yang teratur dan berkelanjutan. (2) Setiap satuan pendidikan wajib memiliki prasarana yang meliputi lahan, ruang kelas, ruang pimpinan satuan pendidikan, ruang pendidik, ruang tata usaha, ruang perpustakaan, ruang laboratorium, ruang bengkel kerja, ruang unit produksi, ruang kantin, instalasi daya dan jasa, tempat berolahraga, tempat beribadah, tempat bermain, tempat berkreasi, dan ruang/ tempat lain yang diperlukan untuk menunjang proses pembelajaran yang teratur dan berkelanjutan. Pemenuhan standar sarana prasarana yang baik tentunya akan semakin menunjang proses pembelajaran itu sendiri.

Fakta lapangan dalam studi awal ditemukan bahwa beberapa peralatan ataupun sarana prasarana yang dimiliki oleh SMA Swasta Pelita Raya Kota Jambi terlihat sudah usang termakan usia, dan sebagian lagi terlihat sudah rusak dari sisi fisiknya. Hal ini membuat penulis merasa tertarik untuk menelusuri lebih mendalam mengenai bagaimana para guru di SMA tersebut memanfaatkan sarana dan prasarana yang ada dalam menunjang proses pembelajaran.

\section{METODE PENELITIAN}

\subsection{Pendekatan Penelitian}

Penelitian ini menggunakan pendekatan kualitatif yang bertujuan untuk mengkaji permasalahan dan memperoleh makna yang lebih mendalam sesuai dengan latar penelitian. Creswell (2012) mengatakan bahwa pendekatan kualitatif pada umumnya digunakan untuk memahami pengalaman manusia dan untuk mengekspresikan perspektif mereka. Satori dan Komariah (2010) dalam Muspawi (2018:18) mengatakan bahwa pendekatan kualitatif merupakan penelitian yang menekankan pada quality atau hal yang terpenting dari sifat suatu barang/jasa. 
Dengan demikian dapat dikatakan bahwa pendekatan kualitatif merupakan penelitian yang berupaya melihat sebuah penomena dari sisi proses pelaksanaannya.

Penggunaan pendekatan kualitatif dalam penelitian ini didasarkan pula atas pertimbangan agar: (1) lebih mudah menyesuiakan jika berhadapan dengan kenyataan ganda; (2) dapat menyajikan langsung hakikat hubungan antara peneliti dengan responden; (3) lebih peka dan lebih dapat menyesuaikan diri dengan banyak penajaman pengaruh bersama dan terhadap pola-pola nilai yang dihadapi.

\subsection{Subjek Penelitian.}

Penelitian ini dilaksanakan di SMA Swasta Pelita Raya Kota Jambi. Penelitian dimulai dengan observasi awal lokasi penelitian, dimaksudkan untuk mengenali secara pasti mengenai tempat dilaksanakannya penelitian. Dilanjutkan dengan proses berikutnya hingga tuntas secara keseluruhan.

Khusus mengenai sumber data yang berupa subjek atau sampel manusia, pemilihannya dilakukan secara purposive dijelaskan oleh Lincoln dan Guba sebagaimana dikutif oleh Moleong (2010:34) bahwa peneliti mulai dengan asumsi bahwa konteksnya sendiri dan peneliti sangat erat kaitannya dengan faktor-faktor kontekstual. Berdasarkan prosedur sampling, maka yang menjadi subjek penelitian ini adalah kepala sekolah, wakil kepala sekolah bidang sarana dan prasarana, dan beberapa orang guru.

\subsection{Tahapan-Tahapan Penelitian.}

Penelitian ini direncanakan melalui beberapa tahapan, yakni mulai dari : Tahap persiapan, yang terdiri atas survei literatur, survei lokasi penelitian, pengidentifikasian data awal, dan pengajuan proposal. Tahap Pelaksanaan, yang terdiri atas pengumpulan data, pengolahan data, analisis data, dan penyusunan laporan awal. Tahap penyusunan laporan penelitian, yang terdiri atas persiapan seminar dan pelaksanaan seminar, penyusunan laporan akhir, dan penyerahan laporan akhir.

\section{Teknik Pengumpulan Data}

Pengumpulan data penelitian ini menggunakan tiga teknik utama, yaitu observasi, wawancara, dan studi dokumentasi.

\section{Observasi}

Menurut Gunawan (2015:143) observasi merupakan kegiatan memerhatikan secara akurat, mencatat fenomena yang muncul, dan mempertimbangkan hubungan antara aspek dalam fenomena tersebut. Observasi penulis lakukan secara berkelanjutan, agar diperoleh informasi dari tangan pertama mengenai masalah yang diteliti, dan diketahui kondisi SMA Swasta Pelita Raya Kota Jambi. Untuk itu, penulis melakukan pengamatan partisipasi aktif dan pasif secara bergantian dengan memperhatikan sifat situasi dan peristiwa yang diamati serta keterlibatan penulis dengan responden.

\section{Wawancara}

Pelaksanaan wawancara pada prinsipnya dimaksudkan untuk mendapatkan data yang cukup sehubungan dengan pokok masalah penelitian yang telah diidentifikasi. Menurut Afrizal (2016:135) salah satu teknik pengumpulan data yang lazim dipergunakan oleh peneliti dalam penelitian kualitatif adalah wawancara mendalam. Kegiatan wawancara ini penulis lakukan secara 
berkesinambungan dengan subjek penelitian dalam berbagai situasi, meskipun kadangkala dilakukan pula dalam situasi yang khsusus.

\section{Studi Dokumentasi}

Selain observasi dan wawancara, penulis menggunakan pula teknik pengumpulan data melalui studi dokumentasi. Menurut Herdiansyah (2010:143) dokumentasi adalah salah satu metode pengumpulan data kualitatif dengan melihat atau menganalisis dokumen-dokumen yang dibuat subjek sendiri atau oleh orang lain tentang subjek. Data yang diperoleh dari studi dokumentasi ini penulis manfaatkan sebagai bahan triangulasi untuk pengecekan kesesuaian data.

\subsection{Proses Pengumpulan Data}

Proses pengumpulan data dalam penelitian ini penulis tempuh melalui tahap orientasi dan overview, tahap eksplorasi (focused exploration), dan tahap member check. Tahap pertama, orientasi dan overview. Pada tahap ini penulis mencari dan mengumpulkan informasi yang diperlukan untuk menetapkan fokus penelitian. Tahap kedua, eksplorasi (focused exploration). Pada tahap ini, penulis mempertajam fokus penelitian agar pengumpulan data lebih terarah dan spesifik. Tahap ketiga, member check. Dimaksudkan untuk mengecek kebenaran data atau informasi yang dikumpulkan. Tahap ini merupakan tahap untuk memperoleh kredibilitas hasil penelitian.

\subsection{Pengecekan Kesahihan Data}

Untuk mengecek kesahihan atau keterpercayaan data penelitian ini, penulis menggunakan kriteria sebagai berikut: (1) kredibilitas/ derajat kepercayaan; (2) transferabilitas/ keteralihan; (3) dependabilitas/ ketergantungan; dan (4) konfirmabilitas/ kepastian. Untuk memeriksa kesahihan data hasil penelitian ini penulis menempuh cara-cara berikut ini. 1. Ketekunan Pengamatan, 2. Triangulasi, 3. Member Check, 4. Audit Trail.

\subsection{Analisis Data}

Analisis data yang penulis lakukan, mengikuti proses sebagaimana yang dianjurkan oleh Moleong (2010:37), yaitu dimulai dengan menelaah seluruh data yang tersedia dari berbagai sumber, yaitu dari wawancara dan pengamatan yang sudah dituliskan dalam catatan lapangan, dokumen pribadi, dokumen resmi, gambar, foto, dan sebagainya. Menurut Sugiyono (2016:89) analisis data adalah proses mencari dan menyusun secara sistematis data yang diperoleh dari hasil wawancara, catatan lapangan, dan dokumentasi, dengan cara mengorganisasikan ke dalam kategori, menjabarkan ke dalam unit-unit, melakukan sintesa, menyusun ke dalam pola, memilih mana yang penting dan yang akan dipelajar, dan membuat kesimpulan sehingga mudah dipahami oleh diri sendiri maupun orang lain.

Adapun prosedur analisis data yang penulis tempuh dalam penelitian ini terdiri atas empat langkah berikut ini:

\section{Penelaahan dan Reduksi Data}

Reduksi data dilakukan dengan cara memilih data yang sudah disusun dalam laporan, kemudian disusun kembali dalam bentuk uraian terperinci.

\section{Unitisasi Data}

Dalam tahap ini penulis membuat batasan untuk setiap satuan data, kemudian mengkodenya sehingga data yang sudah diperoleh ditransformasikan dan diorganisasi ke dalam unit-unit berdasarkan karakteristiknya. 


\section{Kategorisasi Data}

Dalam tahap kategorisasi data ini penulis memilah-milah sejumlah unit menjadi satu kategori tertentu berdasarkan kesamaan karakteristiknya.

\section{Interpretasi Data}

Tahap interpretasi merupakan upaya penulis memaknai data yang telah dikategorisasi dan menggambarkan makna analitik atas unit dan kategori serta keterkaitannya antara satu dengan lainnya.

\section{HASIL PENELITIAN DAN PEMBAHASAN}

\subsection{Hasil Penelitian}

\section{Pemanfaatan Sarana dan Prasarana Belajar di SMA Swasta Pelita Raya Kota Jambi.}

Guru sebagai pendidik dituntut untuk dapat menyelenggarakan pembelajaran yang menarik dan bermakna sehingga prestasi yang dicapai dapat sesuai dengan target yang telah ditetapkan. Setiap mata pelajaran memiliki karakter yang berbeda dengan pelajaran lainnya. Dengan demikian, masing-masing mata pelajaran juga memerlukan sarana pembelajaran yang berbeda pula. Dalam menyelenggarakan pembelajaran guru pastinya memerlukan sarana yang dapat mendukung kinerjanya sehingga pembelajaran dapat berlangsung dengan menarik. Dengan dukungan sarana pembelajaran yang memadai, guru tidak hanya menyampaikan materi secara lisan, tetapi juga dengan tulis dan peragaan sesuai dengan sarana prasarana yang telah disiapkan guru.

Guru membutuhkan sarana pembelajaran dalam menunjang kegiatan pembelajaran. Selain kemampuan guru dalam menyelenggarakan kegiatan pembelajaran, dukungan dari sarana pembelajaran sangat penting dalam membantu guru. Semakin lengkap dan memadai sarana pembelajaran yang dimiliki sebuah sekolah akan memudahkan guru dalam melaksanakan tugasnya sebagai tenaga pendidikan. Begitu pula dengan suasana selama kegiata pembelajaran. Sarana pembelajaran harus dikembangkan agar dapat menunjang proses belajar mengajar. Hal ini disampaikan oleh beberapa Guru SMA Swasta Pelita Raya,

"Untuk sarana dan prasarana peran nya sangatlah besar karena disini kalau tanpa adanya sarana dan prasarana pastinya guru kurang efektif dan kinerjanya kurang dalam

pembelajaran, karena seluruh sarana dan prasarana itu secara visual maupun teori sangatlah mendukung dalam proses belajar."

Hal ini diperkuat oleh Guru yang lain,

"Guru ketika mengajar supaya KBM dapat terlaksana dengan baik tentunya mereka membutuhkan media penunjang, jadi besar sekali peran sarana dan prasarana dalam keberhasilan pembelajaran siswa."

"Perannya sangat besar, karena dengan adanya sarana dan prasarana kelas baik dapat membantu guru dalam pembelajaran di kelas."

Data hasil wawancara menunjukkan sarana dan prasarana belajar sangat dimanfaatkan oleh guru, karena memudahkan guru dalam mengajar serta memberikan kemudahan siswa untuk memahami pelajaran. Hal ini berdampak pada keefektifan kelas dan menunjang kinerja guru dalam mengajar 


\section{Aspek Yang Perlu di Kembangkan dalam Pemanfaatan Sarana dan Prasarana.}

Salah satu aspek yang seharusnya mendapat perhatian utama oleh setiap pengelola pendidikan adalah mengenai pengembangan fasilitas pendidikan. Sarana pendidikan umumnya mencakup semua fasilitas yang secara langsung dipergunakan dan menunjang proses pendidikan, seperti: Gedung, ruangan belajar atau kelas, alat-alat atau media pendidikan, meja, kursi, dan sebagainya. Sedangkan yang dimaksud dengan fasilitas/prasarana adalah yang secara tidak langsung menunjang jalannya proses pendidikan, seperti: halaman, kebun atau taman sekolah, maupun jalan menuju ke sekolah. Data hasil penelitian menunjukkan bahwa dalam aspek pengembangan fasilitas SMA Swasta Pelita Raya belum mampu memberikan fasilitas baru yang menyebabkan beberapa guru kesulitan dalam menjalankan proses KBM. Hal ini disampaikan oleh beberapa guru SMA Swasta Pelita Raya,

"Karena ini berkaitan dengan guru berarti semua bidang studi, seperti sarpras di bidang olah raga harus ditingkatkan, menambah lapangan yang tadinya hanya satu mungkin sekarang harus ditambah menjadi 2 lapangan, untuk mata pelajaran seperti bahasa yang paling dibutuhkan itu adalah lab bahasa."

"Kalau berbicara mengenai aspek yang perlu dikembangkan dalam sarana dan prasarana sekolah, menurut saya kalau masalah pengembangan itu justru di berbagai apek misalnya kebersihan kelas, lalu sarana dan prasarana kelas yang merupakan modal utama siswa mendapatkan suasanya belajar yang kondusif."

Artinya pengembangan fasilitas pembelajaran merupakan hal yang paling penting yang harus dipenuhi karena segala bentuk kegiatan belajar mengajar terjadi dalam kelas, maka dari itu jika ada sarana dan prasarana yang tidak terpenuhi menyebabkan terhambatnya proses KBM serta kinerja guru dalam mengajar tidak maksimal, dan melalui observasi yang dilakukan dan dokumentasi seperti lapangan voli di SMA Swasta Pelita Raya sudah tidak layak karena bentuk dan kondisinya sangat tidak efektif untuk melakukan kegiatan olah raga di lapangan tersebut dan SMA Swasta Pelita Raya juga tidak mempunyai lab bahasa. Seperti yang dikatakan salah satu guru bahwasanya untuk pelajaran bahasa sangat membutuhkan lab bahasa sebagai penunjang pembelajaran.

Setiap program maupun kegiatan selalu terdapat pengawasan di dalamnya, tak terkecuali kegiatan manajemen sarana dan prasarana. Pengawasan sarana dan prasarana dilakukan dalam rangka mengendalikan jalannya manajemen sarana dan prasarana agar sesuai dengan ketentuan yang ada. Fungsi manajemen salah satunya pengawasan, berkaitan dengan pengawasan sarana dan prasarana, perencanaan dimaksudkan untuk memikirkan dan menentukan tujuan pengawasan, menentukan standar pengawasan, siapa yang bertugas, kapan dilaksanakannya dan bagaimana pelaksanaan pengawasan tersebut. Kegiatan pengawasan memerlukan perencanaan yang matang agar tujuan pengawasan itu sendiri dapat dicapai secara efektif dan efisien. Menanggapi hal ini menurut Kepala Sekolah:

"Bahwa aspek yang perlu dikembangkan ialah Controlling. Misalnya kita sudah melakukan

planning dan sudah di organisasikan tetapi kendala muncul di orang-orang yang melaksanakan ini menjalankan tugas atau tidak."

Melalui hasil wawancara dan observasi bisa dikatakan dalam fungsi manajemen yang satu ini harus dikembangkan oleh Kepala Sekolah sendiri karena pengawasan maupun penilaian terhadap sarana dan prasarana sangat penting dilakukan oleh kepala sekolah. Melalu observasi ditemukan bahwa dalam pengawasan seperti dalam penggunaan media belajar proyektor tidak ditemukan adanya buku kontrol yang menyebabkan tidak diketahuinya siapa saja yang menggunakan media 
tersebut pada saat kegiatan belajar mengajar. Jika aspek pengawasan ini tidak diperhatikan maka penyebabnya banyak yang lalai dalam menajalankan tugas dan kewajibannya.

\section{Permasalahan Sarana dan Prasarana: Antara Harapan dan Kenyataan.}

Faktor yang mendukung keberhasilan program pendidikan dalam proses pembelajaran yaitu sarana dan prasarana. Sarana dan prasarana pendidikan adalah salah satu sumber daya yang menjadi tolak ukur mutu sekolah dan perlu peningkatan terus menerus seiring dengan perkembangan ilmu pengetahuan dan teknologi yang cukup canggih. Sarana prasarana adalah salah satu bagian input, sedangkan input merupakan salah satu subsistem.

Sarana prasarana sangat perlu dilaksanakan untuk menunjang keterampilan siswa agar siap bersaing terhadap pesatnya teknologi. Sarana prasarana merupakan bagian penting yang perlu disiapkan secara cermat dan berkesinambungan, sehingga dapat dijamin selalu terjadi KBM yang lancar. Dalam penyelengaraan pendidikan, sarana prasaran sangat di butuhkan untuk menghasilkan KBM yang efektif dan efisien.

Peraturan Pemerintah No 19 Tahun 2005 tentang Standar Nasional Pendidikan yang menyangkut standar sarana dan prasarana pendidikan secara nasional pada Bab VII Pasal 42 dengan tegas disebutkan bahwa:

1. Setiap satuan pendidikan wajib memiliki sarana yang meliputi perabot, peralatan pendidikan, media pendidikan, buku dan sumber belajar lainnya, bahan habis pakai, serta perlengkapan lain yang diperlukan untuk menunjang proses pembelajaran yang teratur dan berkelanjutan.

2. Setiap satuan pendidikan wajib memiliki prasarana yang meliputi lahan, ruang kelas, ruang pimpinan satuan pendidikan, ruang pendidik, ruang tata usaha, ruang perpustakaan, ruang laboratorium, ruang bengkel kerja, ruang unit produksi, ruang kantin, instalasi daya dan jasa, tempat berolah raga, tempat beribadah, tempat bermain, tempat bekreasi, dan ruang/tempat lain yang diperlukan untuk menunjang proses pembelajaran yang teratur dan berkelanjutan.

Tujuan dikeluarkannya keputusan tersebut agar setiap satuan pendidikan dapat menjalankan proses pembelajaran dengan efektif dan efisien dibantu dengan sarana dan prasarana yang membantu guru dalam menjalankan proses pembelajaran nya. Sebagai salah satu sekolah yang masih baru SMA Swasta Pelita Raya berupaya untuk memenuhi segala kebutuhan dan kelengkapan sarana dan prasarana nya sebaik mungkin agar terciptanya sekolah yang mampu memberikan pendidikan yang baik bagi siswa siswi nya sehingga lulusan dari SMA Swasta Pelita Raya dapat menjadi lulusan yang berkualitas. Seperti yang dikatakan oleh kepala sekolah SMA Swasta Pelita Raya,

"Semakin lengkap suatu sarana kita harapkan kontribusi positif terhadap mutu kualitas anak. Dengan sarana yang memadai dan fasilitas yang memadai keberhasilan suatu pembelajaran akan lebih meningkat dan itu berefek terhadap kualitas anak tersebut. Sekolah ini diadakan untuk bisa mendidik sumber daya yang bermutu." (Partisipan 1)

Namun kenyataannya, sarana dan prasarana belajar beberapa ada yang kurang memadai. Melalui observasi awal dilihat bahwasanya kondisi fisik sarana dan prasarana di SMA Swasta Pelita Raya sudah baik dan terpenuhi ternyata setelah melakukan dokumentasi dan wawancara ada beberapa kekurangan yang dimiliki SMA Swasta Pelita Raya dalam hal pengadaan sarana dan prasarana tersebut. Dimulai dari pembaharuan fasilitas serta pemenuh kebutuhan guru dalam hal mengajar, karena SMA Swasta Pelita Raya merupakan sekolah yang masih berkembang tentunya hal ini akan dibenahi sedikit demi sedikit agar terciptanya tujuan pendidikan untuk memberikan pelayanan terbaik bagi siswa. 


\section{Faktor Penghambat Peningkatan Kualitas Sarana dan Prasarana.}

Terdapat faktor yang menghambat peningkatan kualitas sarana dan prasarana sekolah khususnya dalam hubungannya dengan fasilitas dan kinerja guru. Hal ini dikemukakan oleh kepala sekolah SMA Swasta Pelita Raya mengatakan bahwa,

"Biaya. Walaupun sudah mendapatkan bantuan dana bos tetapi kan terbatas dikarenakan jumlah murid yang belum terlalu banyak."

Selanjutnya senada dengan pemaparan di atas, wakil kepala sekolah sarpras mengatakan penghambatnya adalah,

"Faktor penghambat nya di biaya, ketika dana yang diturunkan besar semua akan terpenuhi ketika dana yang diturunkan sedikit, mau tidak mau kita harus mengurangi dan membeli yang menjadi prioritas terlebih dahulu."

Data hasil penelitian ini menunjukan bahwa SMA Swasta Pelita Raya nampaknya masih berjuang dalam memenuhi kebutuhan fasilitas sarana dan prasarana belajar dan belum sepenuhnya mampu mengatasi hambatan yang dihadapi saat ini karena permasalahan utama dalam terhambatnya pemenuhan kebutuhan sarana dan prasarana adalah di biaya.

\subsection{Pembahasan}

Temuan dari hasil penelitian ini menunjukkan bahwa kondisi SMA Swasta Pelita Raya memiliki sarana dan prasarana yang secara fisik sudah memenuhi standar sarana dan prasarana yang sudah ditetapkan dan terlebih untuk sarana dan prasarana belajar. Dilihat dari pemanfaatan manajemen sarana dan prasarana, hasil penelitian menunjukkan bahwa guru sangat memanfaatkan sarana dan prasarana belajar yang ada karena sebagai penunjang proses belajar mengajar dan memberikan kemudahan guru dalam memberikan pelajaran kepada murid sehingga murid lebih mudah memahami pelajaran yang diberikan.

Menurut Matin (2006) sarana dan prasarana pendidikan merupakan salah satu sumber daya yang penting dalam menunjang proses pembelajaran di sekolah. Keberhasilan program pendidikan di sekolah sangat dipengaruhi oleh kondisi sarana dan prasarana pendidikan yang dimiliki sekolah dan oleh optimalisasi pengelolaan dan pemanfaatannya.

Dalam konteks penelitian ini dan dari hasil wawancara, SMA Swasta Pelita Raya masih perlu memperbaharui sarana dan prasarana yang dimiliki, hal ini terlihat dari hasil wawancara mengenai sarana dan prasarana, dimana para guru mendapatkan beberapa hambatan dalam kegiatan belajar mengajar dikarenakan beberapa sarana dan prasarana yang seharusnya diperbaharui tetapi belum diperbaharui hal ini berdampak pada kinerja guru dalam mengajar yang tidak maksimal karena terhambat sarana dan prasarana tersebut. Misalnya, seorang partisipan mengungkapkan "diharapkan agar sarana dan prasarana kelas di sekolah ini menyediakan lampu yang memadai di setiap kelas, karena ada beberapa kelas yang lampu nya mati jadi memperhambat dalam pembelajaran karena ruangan kelas yang gelap dan tidak ada cahaya yang memadai sehingga suasana kelas tidak efektif." Pernyataan objek penelitian ini menunjukkan bahwa belum ada instruksi khusus dalam memperbaharui sarana yang sudah tidak layak tersebut dimana dampak yang didapatkan terhambat serta tidak efektif nya suasana belajar.

Hal ini sejalan dengan penelitian yang dilakukan oleh Septiana (2016) yang berjudul "Pemanfaatan Sarana Prasarana Dalam Proses Pembelajaran IPS Kelas V di SD Negeri Gugus Larasati Kecamatan Gunungpati Kota Semarang." hasil penelitian ini diketahui bahwa guru 
mampu memanfaatkan ruang kelas dengan maksimal, mengikuti prosedur pemakaian sarana prasarana pendidikan dengan hemat dan hati-hati. Faktor yang menghambat guru meliputi terbatasnya dana dan lingkungan yang tidak mendukung untuk melakukan karyawisata. Sebagian guru tidak menguasai media berbasis teknologi, sehingga penggunaan proyektor sangat jarang dilakukan.

Hasil penelitian ini juga beriringan dengan hasil penelitian yang dilakukan oleh Riani (2011) yang berjudul "Hubungan Antara Ketersediaan dan Pemanfaatan Sarana Prasarana Pendidikan Akomodasi Perhotelan dengan Motivasi Belajar Siswa (Pada dua Sekolah Menengah Kejuruan Pariwisata di Yogyakarta)." Penelitian ini merupakan penelitian deskriptif dan asosiatif, dan menurut jenis datanya penelitian ini merupakan penelitian kuantitatif dengan satu variable dependen dan dua variabel independen. Metode pengumpulan data melalui observasi, wawancara dan angket. Penelitian ini menunjukan bahwasanya, (1) Ketersediaan sarana prasarana pendidikan akomodasi perhotelan di SMK PI AMBARRUKMO 1 masuk kategori baik dan SMK KARYA RINI masuk kategori "baik". (2) Pemanfaatan sarana prasarana pendidikan akomodasi perhotelan di SMK PI AMBARRUKMO 1 dikategorikan "kurang baik", dan SMK Karya RINI dikategorikan "sangat baik". (3) Motivasi belajar siswa di SMK PI AMBARRUKMO 1 termasuk "baik". Dan SMK KARYA RINI juga masuk kategori "baik". (4) Terdapat hubungan positif dan signifikan antara ketersediaan dan pemanfaatan sarana prasarana pendidikan akomodasi perhotelan dengan motivasi belajar siswa di SMK PI AMBARUKMO 1 dan SMK KARYA RINI Yogyakarta.

Hasil penelitian ini juga sejalan dengan hasil penelitian yang dilakukan oleh Prasetyani (2009) yang berjudul "Optimalisasi Pemanfaatan Sarana dan Prasarana dalam Peningkatan Mutu Pembelajaran Al-Islam Ke muhammadiyahan dan Bahasa Arab (ISMUBA) Di SMK Muhammadiyah 2 Malang." Penelitian ini menggunakan pendekatan Kualitatif. Data penelitian dikumpulkan dengan menggunakan teknik wawancara, observasi dan dokumentasi. Penelitian ini menunjukkan bahwa SMK Muhammadiyah 2 Malang memiliki sarana dan prasarana yang cukup lengkap, namun dalam memanfaatkannya kurang optimal dikarenakan sarana dan prasarana yang tidak dimanfaatkan secara optimal tersebut merupakan sarana dan prasarana gabungan atau milik bersama antara SMKM 2 Malang, SMAM 3 Malang, MAM 1 Malang dan MTSM 1 Malang karena lokasinya satu komplek.

Tantangan lain yang dihadapi oleh SMA Swasta Pelita Raya adalah berkenaan dengan kualitas sarana dan prasarana. Meskipun pihak sekolah mendapatkan bantuan dana BOS dari pemerintah namun bantuan tersebut terbatas dikarenakan jumlah murid yang belum terlalu banyak. Misalnya, waka sarpras mengatakan, "ketika dana yang diturunkan besar semua akan terpenuhi ketika dana yang diturunkan sedikit, mau tidak mau kita harus mengurangi dan membeli yang menjadi prioritas terlebih dahulu." Artinya kebutuhan pemenuhan sarana dan prasarana belajar di SMA Swasta Pelita Raya terhambat karena biaya. Dengan kata lain, SMA Swasta Pelita Raya dapat memenuhi dan memperbaharui sarana dan prasarana jika dana yang ada pun mencukupi.

Sebelumnya peneliti berasumsi bahwa SMA Swasta Pelita Raya sudah memiliki sarana dan prasarana yang memadai. Namun, hasil penelitian ini menunjukkan bahwa ada beberapa hal yang belum terlaksana dengan baik salah satunya dalam hal sarana dan prasarana yang belum dipenuhi serta terhambat akan biaya. Hal ini memberi dampak terhadap guru dalam proses kegiatan belajar mengajar, karena masih belum memiliki dana yang cukup untuk memenuhi dan mengembangkan fasilitas sarana dan prasarana untuk memajukan SMA Swasta Pelita Raya. 


\section{KESIMPULAN DAN SARAN}

\subsection{Kesimpulan.}

Berdasarkan analisis dan pembahasan yang telah disampaikan, maka dapat dikemukakan kesimpulan sebagai berikut:

1. Sarana dan prasarana belajar di SMA Swasta Pelita Raya sudah memenuhi standar.

2. Pemanfaatan sarana dan prasarana oleh guru di SMA Swasta Pelita Raya telah berperan dalam berjalannya kegiatan belajar mengajar, guru telah memanfaatkan sarana dan prasarana belajar untuk menunjang kegiatan belajar mengajar menjadi efektif serta memudahkan guru dalam memberikan pelajaran ke siswa.

3. Masalah pembaharuan merupakan hal serius yang ditemukan dalam pemanfaatan sarana prasarana di SMA Swasta Pelita Raya. Ada beberapa sarana dan prasarana sudah tidak layak pakai tetapi belum diperbaharui oleh pihak sekolah.

4. Faktor penghambat pemenuhan sarana dan prasarana belajar adalah biaya, dimana pihak sekolah harus menyesuaikan biaya yang dimiliki sekolah dengan sarana dan prasarana yang harus dipenuhi hal ini mengakibatkan pihak sekolah tidak bisa memenuhi sekaligus sarana dan prasarana belajar.

\subsection{Saran.}

Berdasarkan kesimpulan yang diambil maka saran yang dapat diberikan adalah:

1. Pihak sekolah diharapkan memberikan perhatian maksimal terhadap keadaan ruang kelas dan cepat dalam memperbaiki sarana dan prasarana belajar di kelas yang sudah tidak layak agar proses belajar mengajar dapat berjalan dengan efektif, cepat mengambil tindakan ketika sarana dan prasarana belajar ditemukan kendala serta tidak layak dipergunakan karena sangat disayangkan ketika proses belajar mengajar terhambat oleh sarana dan prasarana yang belum diperbaharui.

2. Bagi guru tentunya sarana dan prasarana yang memadai sangat membantu dalam kelancaran proses belajar mengajar serta meningkatkan kinerja maka dari itu diharapkan untuk menggunakan sarana dan prasarana secara maksimal serta menggunakannya sebagai penunjang kegiatan belajar mengajar sesuai dengan yang dibutuhkan

3. Pemerintah dalam hal ini hendaknya memperhatikan kebutuhan sekolah agar segala sesuatu yang perlu diperbaiki dan dibutuhkan dapat terpenuhi dengan baik, sehingga sekolah dapat memberikan pelayanan yang maksimal terhadap murid-murid nya.

\subsection{Ucapan Terima kasih.}

Pada kesempatan yang berbahagia ini penulis mengucapkan terima kasih kepada:

1. Universitas Jambi yang telah memberikan dana untuk pelaksanaan penelitian ini.

2. Jurnal Sosio Humaniora Universitas Jambi yang telah berkenan menerbitkan artikel penulis. 


\section{DAFTAR PUSTAKA}

Afrizal. (2016). Metode Penelitian Kualitatif. Jakarta: Rajawali.

Bafadal, I. (2008). Manajemen Peningkatan Mutu Pendidikan Berbasis Sekolah Manajemen Perlengkapan Sekolah. Jakarta: Bumi Aksara

Barnawi \& Arifin, M. (2014). Manajemen Sarana dan Prasarana Sekolah. Jogjakarta: Ar-Ruzz Media.

Creswell, John W. 2012. Educational research: planning, conducting, and evaluating quantitative and qualitative research, $4^{\text {th }}$ ed. USA: Pearson Educational, Inc.

Depdiknas. (2008). Manajemen Sarana dan Prasarana Pendidikan Dirjen Peningkatan Mutu dan Kependidikan. Depdiknas.

Djamarah, dkk, diakses tanggal 20 Juni 2018. Strategi Belajar Mengajar. http://pasca.unhas.ac.id/jurnal/files/6ac336932b3ec1a415c4767d5cc0684f.pdf

Gunawan, Imam. (2016). Metode Penelitian Kualitatif: Teori\&Praktik. Jakarta: Bumi Aksara.

Herdiansyah, Haris. (2010). Metodologi Penelitian Kualitatif untuk Ilmu-ilmu Sosial. Jakarta: Salemba Humanika.

Kasan, Tholib. (2009). Teori dan Aplikasi Administrasi Pendidikan. Jakarta: Studia Press.

Margono, S. (2005). Metodologi Penelitian Pendidikan, Cet V. Jakarta: PT Bumi Aksara

Matin dan Nurhattati. (2016). Manajemen Sarana dan Prasarana Pendidikan Konsep dan Aplikasinya. Jakarta: PT RajaGrafindo Persada.

Moleong, Lexy. (2014). Metodologi Penelitian Kualitatif. Bandung: PT Remaja Rosdakarya.

Muhfid, Munzirul. (2015). Manajemen Sarana dan Prasarana dalam Upaya Meningkatkan Pendidikan. Skripsi. Surabaya: e-journal-unesa.

Mulyasa, E. (2003). Manajemen Berbasis Sekolah. Bandung: PT Remaja Rosdakarya.

Muspawi, Mohamad. 2017. Penggunaan Metode Mengajar Oleh Guru PAI pada SDN NO.142VII Pulau Aro II Kec. Pelawan Kab. Sarolangun. Jurnal Sains Sosio Humaniora Universitas Jambi Volume 1 Nomor 2 Tahun 2017.

Muspawi, Mohamad. 2018. Implementasi Supervisi Manajerial pada MAN Insan Cendekia Provinsi Jambi. Jurnal An-Nahdhah. STAI Ma’arif Jambi. Vol. 12 No. 1 Januari - Juni 2018.

Peraturan Pemerintah Republik Indonesia No.19 Tahun 2005 tentang Standar Nasional Pendidikan. Bandung: Citra Utama.

Prasetyani, Riki Muklis. (2009). Optimalisasi Pemanfaatan Sarana dan Prasarana dalam Peningkatan Mutu Pembelajaran Al-Islam Ke muhammadiyahan dan Bahasa Arab (ISMUBA) Di SMK Muhammadiyah 2 Malang. Skripsi. Malang: UMM.

Riani. (2011). Hubungan Antara Ketersediaan dan Pemanfaatan Sarana Prasarana Pendidikan Akomodasi Perhotelan dengan Motivasi Belajar Siswa. Skripsi. Yogyakarta: UNY.

Septiana, Ria Ayu. (2016). Pemanfaatan Sarana Prasarana Dalam Proses Pembelajaran IPS Kelas V Di SD Negeri Gugus Larasati Kecamatan Gunungpati Kota Semaran. Skripsi. Semarang: UNS. 
Sugiyono. (2016). Memahami Penelitian Kualitatif. Bandung: Alfabeta.

Undang-Undang RI No.14 Tahun 2005 tentang Guru dan Dosen dan Peraturan Mendiknas Nomor 11 Tahun 2005 beserta Penjelasannya. Bandung: Citra Utama.

Undang-Undang RI No.20 Tahun 2003 tentang Sistem Pendidikan Nasional. Bandung: Citra Utama. 